\title{
Banach's space: Lviv and the Scottish Café
}

\author{
D.Henderson \\ Department of Chemistry and Biochemistry, \\ Brigham Young University, \\ Provo, UT 84602, USA
}

Received August 20, 2004, in final form September 28, 2004

In a sense Stefan Banach is the patron saint of this workshop. He was one of the most prominent former residents of Lviv. His "hangout", the Scottish Café, is shown in the street scene that is the cover of the book of abstracts.

Key words: Banach space, Scottish Café, mathematics

PACS: $01.60 .+g, 02.30 . S a$

In a sense Stefan Banach is the patron saint of this workshop. He was one of the most prominent former residents of Lviv. His "hangout", the Scottish Café, is shown in the street scene that is the cover of the Book of Abstracts of this NATO Advanced Research Workshop and is shown in the poster that is in the background of the workshop photograph. It was hoped that during the workshop we would place a plaque commemorating Banach and the Scottish Café on the outside wall of the building that housed the Scottish Café. However, the plaque was not ready in time.

My first contact with Banach occurred while I was a student at the University of British Columbia (UBC) and was looking at physics books in the university library. I found Banach's book, "Mechanics" [1], which is a very nice treatment, largely unknown in the West. Unfortunately, it has long been out of print. However, several years later I was pleased to purchase a copy of this book in a bookstore in Taiwan. My second contact with Banach was a year after finding his book in the UBC library when I took a course at UBC that included functional analysis and where I learned about Banach and Hilbert spaces. Amusingly, and perhaps appropriately, the definition of a Hilbert space that is found in most physics books is actually the definition of a Banach space. A Hilbert space is a Banach space with an inner product that defines the metric whereas the metric in a Banach space need only be positive and satisfy the triangle inequality.

Twenty years ago I met Myroslav Holovko and Orest Pizio at a conference in Telavi, Georgia. They invited me to visit them in Lviv. I accepted this invitation with pleasure both because of the opportunity to learn more of their work and for 
the opportunity to visit Banach's space. This is now my fourth visit to Lviv.

Banach was one of the fathers of functional analysis and is one of the most important mathematicians of the twentieth century. He was professor of mathematics in Kazimierz University in Lviv. At the time, Lviv was a city in eastern Poland. It is now the city of Lviv in western Ukraine and Kazimierz University is now Ivan Franko University.

He was born in 1892 in Kraków. This is now a city in Poland but at the time was part of Galicia in Austria. One could say that Banach was born in Austria, worked in Poland, and died in the Ukraine without ever leaving Galicia.

Banach's parents never married and he appears to have been raised in some poverty by his grandmother. After completing his studies at the gymnasium in Kraków in 1910, Banach entered the Polytechnical University in Lviv where he studied until 1914. Medical problems excused him from military service during World War I. During the war he attended lectures at Jagiellonian University in Kraków but does not seem to have graduated from either university. Possibly this was due to Banach's hatred of taking examinations.

One notable event that took place in Kraków was his marriage in 1920.

Even though he did not yet have a formal degree, his mathematical genius was already apparent. He wrote several mathematical papers in Kraków. Hugo Steinhaus, who was about to become a member of the mathematics faculty at Kazimierz University, overheard Banach talking about Lebesque integrals in a park in Kraków and spoke with him and became Banach's friend and mentor.

In 1920, Banach was offered a junior position at the Polytechnical University in Lviv. Because he did not have a university degree, Banach was required to obtain special permission from the Ministry of Education in order to proceed to the master's degree examination, a necessary prerequisite for the doctoral examination. In 1920, he presented his doctoral thesis to the Polytechnical University. In 1922, he received his habilitation from Kazimierz University and became a professor at this University.

Lviv was already a center for physics. Smoluchowski, a collegue of Einstein, worked in Lviv from 1900 to 1913 and then in Kraków until his death. However, it is unlikely that Banach and Smoluchowki had much contact or ever met. Banach made Lviv a center of mathematics. Among others, Hugo Steinhaus, Stan Ulam, Stan Mazur, and Marc Kac are well known mathematicians who worked in Lviv during this period. After seminars, these mathematicians retired to a café, called the Scottish Café, for extended discussions.

At first they met in the Café Roma but it seems that the proprietor of the café was unwilling to extend credit in anticipation of the next payday. For this reason and for the more tolerant attitude of the staff of the Scottish Café, Banach and his colleagues moved across the street to the Scottish Café.

The proprietor of the Scottish Café seems to have been remarkably tolerant as during their discussions they wrote equations on the marble table tops. Banach's wife, either because she disapproved of her husband's habit of writing on table tops or because the resultant equations were lost when the table tops were cleaned in the evening, purchased a notebook that replaced the table tops. The notebook was 
left in the custody of the café staff who would produce it when it was requested. Inevitably, the notebook became known as the "Scottish Book".

Their discussions included posing mathematical problems that were written in this notebook. This collection of 193 problems was compiled between 1935 and 1941 . The last entry was by Steinhaus in 1941 about a month before the German invasion. These were genuine research problems, some of which have been solved but some still await solutions.

A café, no longer called the Scottish Café, remained on the premises and I had lunch there in 1989. More recently, the space has been converted to a bank. At least the premises are still devoted to numbers. As I mentioned, an early view of the Scottish Café is used as the cover of the Book of Abstracts. The locals claim that the café received its name because the building was built in the "Scottish style". This escapes me. To me, it looks like a typical central European building.

As World War II approached, many of Banach's colleagues left for the United States. Banach stayed. In 1939, Poland was divided once again and Lviv became part of the Ukraine. Lviv was occupied by Germany during 1941-1944. The Scottish Book was placed in safekeeping during the German occupation. It may have been buried.

The local rumour is that Banach spent the period of the German occupation in a concentration camp and was the victim of medical experimentation. Although he spent a brief period in jail on suspicion of currency trafficking, according to his biography [2] the rumour of spending time in a concentration camp is untrue. However, he lived in difficult circumstances and his health was certainly compromised. The origin of the rumour of medical experimentation is the fact that he was forced to work as a technician in a biological laboratory.

After the war, Lviv again became part of the Ukraine. Banach was offered an academic position at Jagiellonian university in Kraków. However, by then he was seriously ill. He died of lung cancer in 1945 and was buried in Lviv. Orest Pizio took me to view his grave in 1989.

When Lviv became a Ukrainian city, the Scottish Book was taken to Warsaw and was kept by Banach's son, a neurological surgeon. Hugo Steinhaus copied the problems and gave this copy to Stan Ulam in Los Alamos in 1956. He translated them into English and published them as mimeographed notes in 1957. The Scottish Book was published formally in 1981 in a book edited by Mauldin [3].

An excellent biography of Banach has been published [2].

Banach was an outstanding part of the scientific and mathematical tradition of Lviv that started with Smoluchowski and continues today in the Institute of Condensed Matter Physics. I am pleased once again to have visited Banach's space. The participants of this workshop, seen in the workshop photograph, are the unbounded operators in Banach's space. 


\section{Acknowledgement}

The attendance of DH at this workshop was supported in part by NATO and the David M. Kennedy Center for International Studies of BYU.

\section{References}

1. Banach S. Mechanics, Mathematical Monographs 24. Warsaw-Wrocław, 1951. Presumably, originally published in Banach's lifetime.

2. Kałuża R. The Life of Stefan Banach, (A. Kostant and W. Woyczyński, translators and editors). Boston, Birkhäuser, 1996.

3. Mauldin R.D., ed. The Scottish Book. Boston, Birkhäuser, 1981.

\section{Банаховий простір: Львів і Шотландське кафе}

\section{Д.Гендерсон}

Відділення хімії і біохімії, університет Брігхама Янга Прово, США

Отримано 20 серпня 2004p., в остаточному вигляді 28 вересня 2004 p.

По суті, Стефан Банах $є$ покровителем цієї робочої наради. Він був одним з найвидатніших мешканців Львова. Шотландське кафе, завсідником якого він був, є показане на панорамі вулиці, що $є$ титульною сторінкою збірки тез робочої наради.

Ключові слова: Банаховий простір, Шотландське кафе, математика

PACS: $01.60 .+g, 02.30 . S a$ 